\title{
Applying Know - Want - Learn (KWL) Strategy on Teaching Reading Comprehension
}

\author{
Brigitta Septarini Rahmasari, S.S., M.Pd \\ Rengganis Siwi Amumpuni, S.Pd, M.Pd \\ Department of English Teaching \\ IKIP PGRI Madiun
}

\begin{abstract}
Over the last few decades, many instructors have been trying all kinds of teaching methods, but without benefit. Nevertheless, in the 1986, a new technique is appeared which called K$\mathrm{W}-\mathrm{L}$ technique. It is specified for reading comprehension passages because reading skill is not easy matter for students. Therefore, the K-W-L technique is a good one for thinking and experiences. The outcomes of present research appeared that K-W-L enables the students to activate their prior knowledge and operate their thinking.
\end{abstract}

Key words : KWL (Know-Want-Learn), Reading Comprehension, Prior Knowledge

\section{A. Introduction}

\section{Background of the Study}

English learning can not be separated from the four of language skills: listening, speaking, reading, and writing. Without mastering the four language skills, students will not be able to serve, facilitate and manage the teaching learning process. Among the four English skills, reading is the most difficult skill.

The students' problems of reading are: first, the students experience difficulties in comprehending a reading passage. Second, the students' abilities in reading is in the average level. Third, the students are having difficulties to get the main idea and the last, the students are having difficulties to get the message that is carried out by the passage. Meanwhile, the causes of the problems are the students have low interest and low motivation. Also, the teachers uses monotonous technique and seldom uses interesting media. So, it makes students bored and passive in the classroom.

Furthermore, the lecturers faces many challenges in their efforts to help the students to acquire the four basic English skills especially speaking. Because they are lack of motivation in studying English especially to speak English briefly. However, the teacher can use her creativity by using teaching aids to raise the students' motivation and interest in learning and hopefully in acquiring the skills.

To solve those problems, the researcher proposes the use of KWL strategy as a new strategy to increase reading comprehension skill. This strategy believes that one thing can be 
done to boost students' ability in reading comprehension is by exploring their prior knowledge (Ogle, 1986 in Rasinski and Padak, 2004: 186).

\section{Problem Statement}

a. How is the classroom activity for the students when Know-Want-Learn strategy is implemented?

b. What are the advantages and disadvantages of applying Know-Want-Learn strategy in reading classroom for the students?

\section{B. Review of Related Theories}

\section{Definition of KWL}

Reading comprehension is a result of interaction between the perception of graphic symbol that represents language and the reader's language skills and knowledge of the word. Language of the word and the reader's language skill is categorized as the reader's previous knowledge. This is proved that reader's previous knowledge plays a very prominent part in the process of comprehending a written text (Harris and Sipay, 1995: 8).

KWL strategy is one of many strategies that are rarely used in the process of teaching and learning English in the classroom. KWL derives its name from its activity, they are Knowing, Wanting, and Learning. Many experts have delivered many definitions about KWL.

Donna Ogle launched this strategy in 1986. She developed a teaching approach that gets young readers even closer to independent reading comprehension. The idea of this strategy is that the reader must actively and continuously access what they already know about a topic. May (2006: 184) stated that she referred to this strategy as schema matching. Ogle's KWL strategy is a form of schema matching that teaches children to ask specific questions before they read informational material: 'what do I know about this topic?' and 'what do I want to find out?' and it teaches children two other questions right after reading: 'what did I learn?' and 'what do I still need to learn?'

Whistler and Williams (1992: 155) gives another explanation about Donna Ogle's KWL strategy. According to them, KWL strategy is an effective and flexible lesson design that can be applied most appropriately, especially to any non-fiction material about which students have some prior knowledge and background already. In their 
'Literature and Cooperative Learning: Pathway to Literacy' book, they adapt Ogle's KWL strategy to use with cooperative group of four.

\section{Procedures of KWL}

Before the class has begun, teacher gives a brain gym activity to focus the students' attention. In this very first meeting of the implementation of the strategy, students will be working in group consists of four students. Teacher has already made a new classroom map and students should move their seats based on the map on 30 seconds. When all the students are seated on their own places, teacher starts to explain about the mechanism of strategy.

Teacher tells the students about the topic and they start to write on the first column (knowing), and then the next column (wanting). When students are working with their columns, teacher walks around the classroom to see their work. As this is the first time for the students to apply the strategy, teacher should give many examples for the students.

The next activity is reading the text from the teacher about the topic. After reading the text, a discussion about the answers of the second column (W-want column) are written down on the last column (learning). Besides, to know the understanding of the students about the text they are given some comprehension questions to be answered.

\section{Discussion}

\section{Implementation of KWL}

The activities of KWL can be varied depend on the condition of the students and the creativity of the teacher. KWL can be done individually, in pairs, or in group. The topic selection is the most prominent point that should be noticed by the teacher. The topic should be in the students' level and match with their prior knowledge.

Students write the main points about what they already know toward a certain topic given by the teacher. Students start the KWL chart before they read the informational text from the teacher. KWL chart consists of three columns: know-column, want-column, and learn-column. The first two columns are filled before they read the informational text. Students write what they know and what they want to know on these columns.

Before teacher gives the students the text, teacher can do a little brainstorming activity with the students to open the students' background knowledge about the topic. This can also be useful to add some information to the students KWL chart. 
Given the informational text, students preview every paragraph. Teacher gives some time for the students to recheck their KWL chart. Students are given approximately 10 minutes to understand the text and fill their last KWL column. The learn-column is the answer from the previous column and everything they have learned after read the informational passage.

Some of students' questions might not be answered clearly from the text; in this case teacher should record the questions as the discussion materials. The unanswered questions are a good chance to start the class discussion. The answers can be found both on the students' statements on the know-column or based on the agreement of the discussion. In this discussion, teacher serves as a recorder. Before closing the class discussion, teacher asks the students to answer some comprehension questions about the text and finally make summary of what they have read. The purpose of writing a summary is to help students keep what they have read in their head (Kinsella; 2001:46). It helps students identify the most important point in their reading activity.

\section{Advantages of KWL}

a. Student will be accustomed to do discussions with their friends

b. They will have more confidence in giving their opinion in the classroom

c. As the topic is interesting, students will be curious and they will have more motivation to read

d. When students are accustomed with this strategy, they will need less time to read

e. Students will become more active in the classroom

f. Students will be accustomed to make a summary

g. Increase students' writing ability

h. Increase students' speaking ability

i. Increase students' listening ability

j. Increase students' vocabulary

\section{Disadvantages of KWL}

The disadvantages of this strategy are put on the mechanism of it. Although this strategy can be done in many ways, but this strategy will be better applied in group. However, this makes teacher spend more energy in distributing the sheet for the KWL chart especially when the columns are made on different sheet.

Another disadvantage might also come from the selection of the text. It becomes difficult when teacher does not understand what the students like. Teacher should spend 
more time to study the students' world in order to get know them well. But this can also be a good way for teachers to enlarge their knowledge in the perspective of the students' point of view.

\section{Conclusion}

From the analysis, it can be concluded that KWL (Know-Want-Learn) strategy can be applied well in the classroom. The gist of this strategy is activating students' prior knowledge in comprehending an informational text. By activating their prior knowledge, student will be able to understand reading texts better than they have to read them in a traditional way. This strategy asks students to think before they read. Thus, the new information they will get is the combination between their prior knowledge and the new information front the text they learn. This makes their knowledge more perfect and the new information they get will remain longer in their mind.

By learning the example of the result of the observation checklists, it can be seen that the classroom activity runs well and students are motivated to read the text. Students' are enthusiastic in following the KWL activity because teacher presents the strategy in a varied and interesting material. Although students are facing some difficulties in the early cycle, but the obstacles are minimized in the next cycle. Thus, the classroom activity runs fairly well during the implementation of the strategy.

Students' responses towards the implementation of KWL strategy are unpredictable. From the results of the questionnaire, it can be seen that students' responses are almost positive in almost all matters. Teacher's technique is considered good by the students. The point that the strategy is advantageous is also admitted by the students. They find that the implementation of the strategy is useful because they can increase their English skill such as reading (especially in comprehending a text), listening, speaking, and even writing. Students' role in the classroom is also increasing. They have more confidence in uttering their opinion about something in front of the classroom.

As the classroom activity and students' responses towards the strategy is good, the students' achievement is also increasing. The results of the reading comprehension test shows that all students have reached the standard score and the increasing score is balance and even get better in every cycle. For students, reading activity in this strategy is interesting. This strategy throws the students' opinion that reading is boring and confusing. This strategy 
brings a new understanding that reading is a joyful activity that everyone will get interested in.

Finally it may be ensured that the KWL strategy is a suitable strategy to enhance the reading comprehension ability especially for students and the next turn, it is possible that the students' language skills will increase.

\section{References}

Carr, E. \& Ogle, D. (1987). K-W-L Plus: A Strategy for Comprehension and Summarization. Journal of Reading, 30 (7), 626-631

Conner , Jennifer(2006) Advanced study of the Teaching of Secondary school Reading . Instructional reading strategy . http : \ www . Indiana . edu \$1517 \backslash$ KWL. Htm .

Huffman, L.E. 1998. Spotlighting Specifies by Combining Focus Questions with K-W-L. Journal of Adolescent \& Adult Literacy, 41(6), 470-472.

Jones , Raymondc . (2007) strategies for Reading Comprehension. htti \ www . reading quest . org $\backslash$ strat $\backslash \mathrm{kwl}$. html .

KWL table ( 2009) KWL table . From Wikipedia , the Free encyclopedia . Inc , non-profit organization .

Michael , Susan (1998) KWL - A Reading comprehension strategy . An Educators Reference Desk Losson plan

Tierney, Robert J., John E. Readence., dan Ernest K. Ristner. (2008). Reading Strategies and Practice A Compedium. Boston: Allyh and Bacon 